\title{
Evolving Management Practices in the Czech Republic: Restructuring and Market Orientation*
}

\author{
Ronald Savitt ${ }^{* *}$
}

This article examines the market orientation activities of four firms in the Czech Republic. The findings are framed in terms of organizational innovation. Two firms have successfully adopted such practices, however, they had the advantages in one case of being a start up and in the other having the direction of its international parent. The other two are traditional old state enterprises that in spite of having gone through formal restructuring have not made substantial progress in shedding the management processes of the past. The findings suggest that restructuring with current practices and procedures does not foster the innovative environment necessary to move old state enterprise toward marketing practices.

In diesem Artikel werden die Aktivitäten zur Marktorientierung bei vier Firmen in der Tschechischen Republik untersucht. Die Ergebnisse sind in den Rahmen organisatorischer Innovationen gefaßt. Zwei Firmen haben marktorientierte Praktiken erfolgreich eingeführt. Sie waren jedoch im Vorteil, da es sich in einem Fall um eine Neugründung handelte und im anderen Fall die Hilfe des internationalen Mutterunternehmens in Anspruch genommen wurde. Die anderen beiden sind traditionelle alte Staatsunternehmen, die, obwohl eine formale Umstrukturierung stattgefunden hat, keine bedeutenden Fortschritte bei der Überwindung der alten Unternehmensführungspraktiken machen konnten. Die Ergebnisse der Untersuchung deuten an, daß Umstrukturierung mit den momentan üblichen Mitteln keine genügend innovative Atmosphäre dafür schafft, in alte Staatsunternehmen marktorientierte Praktiken einzuführen.

\footnotetext{
* manuscript received: 27.11 .97 revised: 15.07 .98 accepted: 28.07 .98

** Ronald Savitt, John L. Beckley Professor of American Business, The University of Vermont, School of Business Administration, Kalkin Hall, Burlington, Vermont, United States of America
} 


\section{Introduction}

This discussion provides a disciplined look at the transformation of management practices with regard to market oriented practices in the Czech Republic. The purpose of the study is to determine how the restructuring of old stateenterprises has begun to affect the management practice. The prime evidence comes from several in depth case studies as well as the preliminary results of a major study of 76 Czech firms. While it is difficult to extrapolate to the economy as a whole, the findings provide insights about restructuring and the development of market orientation. Although macro economic measures suggest improvement in the performance of the Czech economy and its industrial structure since the Velvet Revolution, less is known about marketing and management practices in the Czech Republic than elsewhere (Hooley, Beracs, and Kolos 1993; Akimova 1997). The present discussion closes this gap.

The Czech Republic along with Hungary, Poland and Slovakia are thought to have reached a convergence point with many western market economies as measured by traditional economic measures, living standards, inflation rates, dominance of the private sector, debt management practices, and access to capital markets ("Bonding Well," 1996, p. 22). With regard to privatization estimates suggest that in 1996, more than 70 percent of the gross domestic product is accounted for by the private business. On a scale in which Italy received "4," the Czech Republic was ranked "3" ("Private Parts, December 1996/January 1997, p. 68). A recent World Bank study based on 1992-94 data offers three observations about large Czech industrial firms in contrast to others, Bulgaria, Hungary, Poland and Slovakia. First, Czech firms have restructured the most; second, systematic restructuring has been carried out at a faster rate; and, third, "exports have grown most in the Czech and Slovak Republics" (Pohl, Djankov, and Anderson, 1996, p. vii). The latest World Bank analysis provides further evidence of the performance of Czech firms. In 1995, 73 percent of Czech firms, weighted by employment, were profitable and 98 percent of Czech firms had positive cash flows. Both represent the highest performance of firms in the larger sample that included Romania and Slovenia (Pohl, Anderson, Claessens, and Djankov 1997, Table 3., p. 6; Table 5, p. 8). As impressive as they are, the data say very little about what practices management have employed and whether such practices will carry Czech firms through the next period in the development of the market economy.

\section{From Enterprise Transformation to Market Orientation}

\section{Restructuring}

All state enterprises in the Czech Republic were required to prepare formal restructuring programs which were to prepare them to face the market economy (Matesova 1994, p. 24). Restructuring is a three part process that aims at 
transforming the structure and behavior of the old state enterprise into a business not that dissimilar than is found in any market economy. Although all three parts may take place at one time, it is appropriate to consider them sequentially (Frederick 1994, p. 64). The first is legal restructuring that represents the change in the pattern of ownership that moves the enterprise from state ownership to some form of a joint stock company controlled by a board of directors that is responsible to stockholders. This process is generally referred to as privatization. Financial restructuring is the second part of the process. It is characterized by actions that affect the structure of balance sheets and income statements. Decisions in the former deal with the status of assets and liabilities while those in the second case affect costs and revenues. The last dimension is concerned with the revising the organization's structure and developing new operational methods. Structural changes include actions taken toward the organization of departments, the internal hierarchies, lines of accountability, lines of communication, and manpower issues. Operational restructuring focuses on changes in production processes, the use of new technology, development of supply relationships and distribution systems, and all aspects of marketing, especially marketing research and product development. It is in operational restructuring that the greatest changes with regard to market behavior are expected. Here is where the strategic programs are developed and implemented. Examining what takes place here provides an indication of the degree to which an organization is becoming market oriented: "it is the most significant way that firms have been developing a long-run strategy for the market place" (Estrin, Gelb, and Singh 1994, p. 151).

\section{Structural change and market orientation}

Structural change is an important part of the transformation process. Its purpose is to remove the traditionally highly structured, top down management with unique hierarchies, and create a flatter organization that is focused on the market. This is often characterized by adding the marketing function through the establishment of a specific department or making the entire organization market oriented. Both have been used to integrate a number of previous such as packaging, distribution, and sales into a single unit. Often such units have expanded by adding other, new marketing activities including research, new product development, and promotion (Hitchens, Birne, Hamar, Wagner, and Zeinplinerova 1995, p. 101). The central goal of these changes is to build better relationships with consumers (Edwards and Lawrence 1994, p. 64). Such structural changes are not minor; however, they do not necessarily represent the development of a market orientation. Having a market orientation goes beyond having a marketing department (Lamb, Harr, and McDaniel 1994, p. 10). It represents a commitment that supercedes the role of a single department, no matter how well managed. In an extensive study of a transforming East German pharmaceutical firm, researchers concluded that even in spite of recognizing the 
need to engage in marketing activities and the establishment of a marketing department, the firm had difficulties that were inherent in marketing itself let alone the larger concept of market orientation. "There appeared to be a problem within the company with understanding the role of marketing (rather than sales). This was compounded by the cost of marketing activities and the internal lack of experience" (Edwards and Lawrence 1994, pp. 75-76).

Market orientation goes beyond the establishment of a marketing department or engaging in marketing activities. The movement toward sales and marketing activities by transforming enterprises and all that means, it should not be mistaken for engaging in a market orientation strategy. There are many examples in which "Quality, customer orientation, and competitiveness became the mantras of top management in 1992" in the Czech Republic (Newman and Nollen 1996, p. 129), however, they were not part of a comprehensive way of managing the enterprises. A market orientation transcends marketing activities and other management functions. It can best be thought of as "the strategic direction for a business and plays a critical role in achieving a business's longrun objectives with respect to growth, financial performance, and strategic market position" (Best, 1997, p. 267).

Market orientation has been the focus of intense theoretical development and empirical research over the past decade. It is defined by most scholars with a common set of characteristics: "three behavioral components-customer orientation, competitor orientation, and interfunctional coordination-and two decision criteria-long term focus and profitability" (Narver and Slater 1990, p. 2 ). The level of market orientation in any business is the degree to which the business (1) obtains and uses information from customers; (2) develops a strategy that will be meet customer needs; and (3) implements that strategy by being responsive to customer needs and wants" (Ruekert 1992, p. 228). The purpose of this research was to develop a basic understanding of what marketing managers saw as required changes to be successful in the market economy. There was no expectation that market orientation as seen in western market economies would be present. Rather what was sought was an understanding of how far these managers have gone in that direction.

\section{Restructuring and marketing as organizational innovation}

The introduction of marketing practices and market orientation can be examined as part of organizational innovation. Although much of that discussion focuses on pure technological issues, the concepts comfortably covers theses ideas as part of the general set of issues contained in "managerial technology" (Brown 1991, p. 152). Organizational transformation in the Czech Republic closely matches the concept of punctuated equilibrium in which the requirement for the introduction of "commercial" or marketing plans represents the dramatic shock to the past system that forces managers to introduce new operating methods 
(Romanelli and Tushman 1994, p. 1141). Although Czech managers had a mandate to introduce marketing as part of their enterprise-restructuring plan, little direction was given to what it should be. They had to discover and develop what they though marketing were and they had the responsibility for seeing that whatever it was they came up with diffused throughout the enterprise. This process closely represents the start of a continuous process of innovation. How well marketing diffuse as we will examine more fully later is directly affected by both external and internal factors.

\section{Research design}

The research is exploratory and represents the initial stage of a much larger study of market orientation. These cases were developed to clarify basic concepts as well as provide a framework for understanding how top management in these firms defined the new market conditions. Of great interest was the ways in which managers were beginning to define the practices that they were employing. The cases also established an understanding of the effects of restructuring on their behaviors. The cases represent four firms operating in the Czech Republic; all of the firms had gone through restructuring, that is, they all were private firms and they all had marketing departments. Of the four, one was a new entrepreneurial development in wholesaling; another was a Czech subsidiary of a multinational firm and the remaining two were non-competing firms in the petrochemical industry. The latter three were restructured, the first by management mandate and the other by legal direction. The choice of these specific firms was arbitrary though inclusion of old state enterprises was critical since they account for such a significant proportion of the Czech economy. The interviews with the petrochemical firms were conducted in Czech, the other two in English. In each case the individuals interviewed had primary responsibilities in marketing. The questions in each interview followed the extended behavioral components of market orientation introduced earlier although there was no direct questioning about the decision criteria of long run focus and profitability. The respondents represent the "top management level, that reports to the operating board and supervise the business functions. Their position was purposefully selected because of their key role in these organizations.

The behavioral components were made operational as discussed as following. Customer orientation is defined by a shift in the firm's behavior from the production orientation of the past to some set actions that recognized the role of the customer in the firm's decision making process as limited or extensive as that might be. Competitor orientation is present when management considers what actions its competitors might take as a result of its decisions. Interfunctional coordination is seen to be present whenever one of the following three business functions, accounting and financial management, human resources management, and production, are combined with marketing in the firm's decision making process. Implementation incorporates three distinct 
elements that evaluated as above. There has been no attempt to assess whether implementation of any of the three represents full implementation, that is, its elements not the full component is evaluated. The first is whether or not management collects and uses customer research; the second is whether or not management develops a strategy to meet customer needs; and, finally, the third is whether or not the firm implements that strategy by being responsive to customers. In each case several questions were asked to obtain responses and the final evaluations were made on the basis of multiple answers.

Each case was carefully evaluated to determine whether each of the components was present and the degree to which they had been implemented. Credit was given to implementation even in those cases in which it was not clear as to whether the respondents fully understood the concepts.

\section{Does Market Orientation Exist?}

\section{An overview}

Surprisingly some elements of marketing orientation do exist within the four cases. Less surprising is that Hewlett Packard, the subsidiary of the multinational firm, has a strong market orientation program that is part of the firm's international operations. Another impressive example is found in the entrepreneurial operation that basically started from scratch as a result of economic transformation. In the other two cases, there is no clear development of market orientation strategy. Some evidence that basic elements are present and managers, though not fully aware of what it is, have engaged in a number of programs to move their companies ahead so as to operate better in the market economy. The evidence from these two cases provides insights as to what is necessary to develop a market orientation as well as the factors that constrain its adoption and implementation. In order to appreciate the findings, a brief description of each of the cases is necessary.

A summary of the case analysis is found in Table 1. Joran and Hewlett Packard closely approximate the components of market orientation while Kaucuk and Spolchmie do not. What is interesting is that the latter two began a restructuring process much earlier than an others; however, they are plagued with the challenges of dealing with the old ways. Both have organization charts that clearly identify marketing departments. As will be seen, top management in these organizations does not have clear ideas of how to move from the structures in the charts to purposeful functional actions.

\section{JORAN CS spol. s. r. o.}

JORAN is a full line merchant wholesaler and retailer of construction tools, electric power tools, accessories and construction adhesives and fixing for 
concrete, steel and wood located in Brandys nad Labem about 20 kilometers north of Prague. The firm was originally established as a sales agent for drill bits in 1991, then became part of a Danish joint venture and returned to a single proprietorship in 1994. In October 1997 Joran became part of a German joint venture. Foreign firms supply all of its products and this has resulted in the firm's early success. Sales grew at a rate of 50 percent in 1995 over 1994 and at a rate of 30 percent in 1996 over 1995; the rate of growth for the first 9 months of 1997 was 10 percent. Their success comes from a clear commitment on the part of management to market oriented practices. Although they have not fully implemented all of the components, they have clearly developed a systemic program in that direction. Their mission statement states that their interests are to "...satisfy the needs of customers at high quality through selling tools, instruments and fixation technologies with maximum effectiveness and efficiency both in the short-term and in the long-term." "JORAN regards itself as a full-service wholesaler serving both merchant and industrial segments with a full product line in which the greatest attention is paid to customer training, technical assistance and advice and rapid shipment (24 hour) of merchandise."

The operations are driven by information. Research on the environment, competition and current and potential customers is merged with internally generated financial and operating data. The sales staff is part of the information gathering activities and they are expected to continually ask customers: "What are you willing to purchase from us?" Market research supports customers and their customers. Management is greatly concerned about understanding what competition is all about. With little available information, they have to think carefully about their own programs. They have established a very aggressive marketing effort totally based on what they know about consumer needs and hope that this will suffice until they are able to develop a competitive strategy based on an understanding of competitors.

Customers are segmented by purchase characteristics, profitability, and ability to pay factors. They market differently to the various segments and have been successful in developing specific plans to certain segments based on their needs. For example, using the ability to pay factor, they were able to develop a program that used credit facilities for increasing business. JORAN established its own VISA credit card program and have used it to stimulate sales by providing discounts for customers using the card. It has focused on that group that would be best for increasing their revenues. Clients who obtain this credit vehicle receive 5 percent discounts on purchase of over $\$ 250$. Thus increasing sales as well as improving cash flow. The organization is flat and market information is widely shared among the management functions. They are proceeding on a "best practices" approach and have modeled some of their operations and objectives on benchmarking. JORAN is a member of the Specialty Tools and Fasteners Association in the United States. Comparisons are made between its operations 
and those of similar sized North American firms. Management believes that "we are doing as well as the best firms in our category."

A singular advantage that JORAN has been able to exploit is that it is basically a new venture. Owners and managers did not have to deal with the legacies of the past. They understood that if they were going to be successful they would have to develop procedures that would allow them to compete in the developing market economy. As part of their recognition, they sought out management education and enrolled in courses at the Czech Management Center. The ideas of market orientation and strategic development literally flowed from the lectures and books into practice.

\section{Hewlett Packard}

Hewlett Packard (HP) has been operating in Czechoslovakia since 1968 as a branch of the Vienna operations; it became a wholly owned subsidiary in 1991. The shift to a market orientation format started in 1996 as part of the changes in the parent company. Within the Czech context, this was associated with the infusion of more domestic and foreign competitors. Although these offer the same assortment level and services, they did come into the market at lower prices and were successful in undercutting HP's brand loyalty. Competitors actively exploited the worsening exchange rates and the pressures both in the governmental and industrial sectors to cut costs. The market shifted dramatically, to the point that it is driven almost exclusively by price. HP's response began with extensive research to clarify what consumers really wanted and to better understand the nature of "price driven" as a means of formulating new marketing programs. Although the major activity had always been marketing and sales, the organization was structured in accordance with the types of computing equipment that was offered. Several different divisions of HP would call on the same customers and many cases the same individuals. Customers could not distinguish HP marketing UNIX based systems from ITNEL based systems; the former were sold directly while the latter were sold through distributors often to the same customers. There was dramatic confusion between the two systems for customers who loyal to HP products were really not certain who or what HP was. In spite of its American origins, HP looked very much like a product driven enterprise and to complicate matters there was dramatic internal competition.

As a result of better understanding customers, HP reorganized itself so that it now offers integrated solutions to computing problems rather than supplying hardware and software. The organization is developing the image that it is a single source with multiple solutions without regard to the combination of hardware and software that create them. Where they could not meet competitors, they moved on to market segments where they could integrate consulting services, systems, and service. To better serve customers needs and wants and 
thwart competitors, HP created alliances with a wide variety of domestic and foreign firms, some competitors, in the development of integrated "problem solving systems."

Within the first six months of the market orientation, approximately 30 percent of the business came from the service-based business. The prospects for expanding this type of business on the one hand is very good and on the other potentially limited. Czech operations have been the most successful. The have had the highest proportion of revenue from the new orientation of any of the HP subsidiaries, suggesting that, in spite of market confusion, that they had the potential of being market oriented years before but had not moved ahead because of their unique position of being the only western computer supplier. While there is great demand for the new systems based problem solving approach for new business, the real challenge will be convincing the large system users to switch to the HP approach in the next several years and then the replacement of such systems as they become obsolete.

\section{Quack}

Kaucuk is a major Czech petrochemical firm that has not been able to fully shift to a market orientation and shake off old practices. What management has put into place is a marketing department with a variety of responsibilities, basically it is both a strategic function and an operating division. Their emphasis aims at the development of "direct contact with clients," however; the program has not been clearly defined. If anything, the restructuring has created what management described as a "marketing orientation." Basically this appears to be the centralization of activities for collecting market data.

The firm's strategic planning division, a throw back to the internal central planning function though now carrying the new title of marketing. Management collects vast amount of market information. The firm purchases conceivably every data source that has something to do with the petrochemical industry, regardless of whether the data relate to their products and markets. The central concern is to discover as much about consumers as possible, both domestic and foreign. However, management readily admitted that very little is done with the data in spite of sophisticated computing facilities. Most of the data are "massaged" in a variety of forecasting models. The forecasts are very narrowly defined along product lines though special studies are performed for specific products. While they have the capacity to analyze data, they do not know how to apply it making marketing decisions. Market information is also developed from sales activities. The sales force has begun to collect additional information from their current clients; however, the data are neither shared across the various product lines nor moved back up into the planning process. Each salesman holds on to the information that he collects. There is great suspicion among them that their colleagues would exploit these contacts if the information were shared. 
Also, they are afraid if their information is incorrect or their clients do not perform to the standards that are set that the salesman will be held responsible. A secondary use of the data is in SWOT analysis to guide the overall development of strategy. Management is keenly aware of the linkage between the data they collect and the planning function although they have never completed a major studies linking the two. The current exercise focuses on the market for building materials, primarily for insulation materials, where they believe they have a competitive advantage. The purpose of the study is to measure the consumption of these materials by specific markets and users. What they have been able to do so far is to forecast the total volume of demand in the Czech Republic. For the first time, competitors have been incorporated in the analysis.

Management speaks concretely about major foreign competitors; however, they have not thought about what plans they need to implement in order to compete with such firms as BASF. It is not clear how far beyond attempting to offer lower prices; they have come to thinking about a competitive strategy. To date, Kaucuk has not gone directly to their customers to find out what they want. While managers recognized that paying attention to customers needs was going to be important, they also expressed the view that customers may not be ready for such practices. They basically want to supply insulation products to their customers and basically were only concerned with price. The marketing of petrochemical products is still viewed as a technological function based on the production of the products and their effective delivery. Paying attention to customers is when there is a problem arises and there it is the technical response that they see as critical.

The organization is still extremely hierarchical with a strong top down decision making structure and it appears that the net result has been to give production more authority. As part of restructuring they became decentralized and many of the products were transformed into free standing businesses, some of which were eventually put up for sale. Consolidation of all of the basic management functions took place at the top of the organization where marketing and strategic planning were added to accounting, finance, human research management, information technology, production and research and development. Marketing and strategic planning were integrated into the Strategic Management Department. It is a staff function and basically serves the top management group in planning activities. While there have a number of efforts to develop plans, very few have ever been implemented and they are used as evidence when government ministers inquire about transformation issues.

Except at the very top of the organization, there has been little success in the coordination of the various management functions. To the extent that this is a start the real success lies in how that method is passed down through the organization. The top management represents the old system. More than 7 are 
over 50 years old and only one is under 35 . While middle managers are relatively young, they were not brought into the old system and even those who see the need for change are not being brought into the positions where their decisions can have an impact. Historically, this was one of the best companies in the country; it provided stable employment and excellent benefits and salaries, to its employees and it is also located close to Prague. But in spite of having moved through the first stages of restructuring, Kaucuk has not changed dramatically. Those changes that have been made may not prepare it for the future. As with almost all companies in the country it has not developed a strategy for either internal or external markets. Success in the latter is premised on further devaluation of the currency rather than active market participation. What we have here is one of the best of the old state enterprises setting sail without clear direction of the requirements of what it is to be market oriented. They have taken up the cause of marketing and strategic planning but in general have not moved far from the old production based approach.

\section{SPOLCHEMIE (Spolek pro chemickou a hutni vybrobu, a. s.)}

SPOLCHEMIE is one of the most important firms in the Czech petrochemical industry. It was founded in 1856 and has experienced all of the economic machinations of the twentieth century. In 1994 it returned to private status. The company is organized into three chemical divisions along with central support functions. Senior management reports to the Board of Directors and that group with shareholders determines company policies as well as direction for all of the basic management functions including marketing. Major interest is in the development of a more flexible organization to support the various activities. The direction for advancement has been established: "We will increasingly depend on marketing and on the potential of our employees for our development." Management has an adopted a clear and strong mission statement: "Our business is not producing or selling products, but solving the problems and meeting the needs of our customers."

In spite of the interest in becoming market oriented, the development and implementation market oriented activities has been particularly difficult. Marketing is in great disarray as a result of restructuring programs. An enterprise wide marketing department was established in 1968 to serve expanding foreign markets. The department was not that dissimilar with others and operated on a top down formula. More recent marketing organizational efforts have placed marketing horizontally, providing help to each of the three divisions. Central management still is responsible for the development of marketing plans and these are focused on consumer needs. Though labeled marketing, the activities reflect still the production orientation of the past. Product development remains the central function and efforts do not include customers. Marketing skills are production and product knowledge, product applications, and technical problem solving. 
While the consumer is defined as the center of management's focus, in reality there is little evidence support that. While some data are collected from directly from consumers, it is basically demand estimates; not information about wants and needs. Such data are collected in each of the three divisions though there is no evidence that that any of it is shared among them. Secondary data from other sources including the government, journals, research agencies, and trade associations are collected but once again in each of the divisions. Much like Kaucuk the primary use of the data is to forecast market demand.

Central management has identified Austrian and German firms as the major competitors with regard to new products and technical changes and Polish and Slovak firms with regard to price driven competition. What little research is done about competition is limited to the understanding of the technology behind their competitors' products and management has not been able to develop policies to react to either type of competitor. Except at the top of the organization there is little inter functional coordination or cooperation. In the marketing area, managers share little of their marketing programs and little of their research findings. The marketing manager of one of the division remarked during the interview that he was thinking of purchasing products from one of the firm's competitors in another division to sell to his customers! These products were better and cheaper and he did not believe the other division could market to his client. Top management talk about marketing but they seem to have little understanding about what it means. There presented a range of definition including advertising, marketing research and sales.

\section{The Findings}

Both JORAN and Hewlett Packard have adopted and implemented sophisticated market oriented programs for different reasons. In the case of JORAN, the strategy came as a result of management participation on Marketing and Strategic Planning courses at the Czech Management Center. The company was built around the basic concepts and while not all elements are fully in place management clearly understands each of the components, how far they have come and how far they must go to complete the strategy. Hewlett Packard's Czech market orientation program is a direct result of the market orientation plan that has been developed and implemented on a world wide basis that included adaptation to local conditions. Their program meets the test of this research and in almost each of the components has been able to develop elements that bring them close to what the optimum market orientation program might look like. Each company has a singular characteristic that provided direction for becoming market oriented. For JORAN, it was the opportunity to start de nova and for HP it was the connection with a larger and progressive foreign parent. These two factors may well be important factors in determining the degree to which individual firms adopt market oriented programs. 
Kaucuk and SPOLCHEMIE, on the other hand, represent typical old state enterprises that have gone through restructuring a focus on legal and financial restructuring. Although organizational restructuring was an integral part of the process, the results suggest that the issues involved in becoming market oriented simply were not understood. In great part this stems from the fact that the old managers became the new owners and managers. The process was flawed to the extent that it was done without the assistance of foreign consultants. The old visions of marketing were moved along into the present from the past. Because of these factors, little resources were allocated to developing marketing. Clearly the demands for improvement in production facilities dominated, however, the opportunity to link the new facilities with market needs was missed. The production-oriented activities of the past have been put in new clothing. The financial restructuring has given temporary breathing room to enterprises such as these but as more competitors enter the Czech market and as they loose some of their cost advantages, the absence of market oriented programs may be damaging. What ever the future brings, firms such as these will have great difficulties in the ever-expanding market economy.

With regard to the organizational innovation a number of factors clearly stand out with regard to both environmental and enterprise dimensions. Innovation in the former case proceeds most rapidly when there is substantial competition among firms. Among these firms except for Hewlett Packard, competition was not well understood by management. Competition had not been experienced by any of the others and although they recognized that there were new firms in their markets, they did not understand how to react to them let alone develop competitive programs that would force the other firms to react to. The development of competitive practices was to be an outcome of the entire transformation process and hence can not be thought of as a positive element sustaining the development of market orientation. Competition in itself is an innovation.

Among the 76 old state enterprises that are the subject of the larger study, there are some signs of innovative practices though they are far from what western firms undertake and still further away from market orientation. One of the most dramatic changes among these firms has been the increased attention on the collection of market data, some of which goes beyond traditional macro economic statistics to customer characteristics. The collection of data in itself should be regarded as an innovative action that may well bring others. What the findings suggest, however, is that while 80 percent of the firms collect such data, only a small proportion, around 14 percent use it in making marketing decisions (Savitt 1998). Almost half of the firms 39 equate the collection of marketing data with marketing.

Within the firm there are two important elements that affect the rate of organizational innovation. In this case, management attitudes and conflicting 
goals. Managers of old state enterprises still represent the past in which marketing was if not viewed as unnecessary was considered evil by the nature of its capitalistic orientation. Over 74 percent of top managers responsible for the introduction of marketing in sample of 76 old state enterprises had been employed with them for more than 16 years. "There is a continuity of the postcommunist senior managerial group with its state socialist predecessor" (Clark and Soulsby 1996, p. 300). Such people are simply not innovators especially with regard to programs that are basically counter to their ideologies. As a result managers in general do not have a strong understanding of marketing let alone market orientation practices. To the extent that restructuring has brought changes these have been in the context of working through conflicting goals. The government placed dramatic goals for cleaning up the environment and investing in non-polluting technologies. Both of these activities require vast sums of money that might have been allocated toward new plant and investment and marketing activities. Even if the will for innovation were present, it is realistic to believe that the resources would not have reached these ends.

"In short, it has proven impossible to erase 40 years of state socialism, ideology, institution and behavioral patterns, and simply inscribe the new values, structures and the proper conduct of market capitalism" (Clark and Soulsby 1995 , p. 216). While restructuring may provide the framework for the development of marketing activities and market orientation programs, the environment does not fully support the innovative process. It provides the opportunity but does not eliminate the barriers for innovation. To the extent that past managers is responsible for developing future plans, restructuring has incorporated the seeds of defeat. The discipline of the market may be the best approach to support the innovation process. Its success clearly depends on how quickly old state enterprises can react to them and that goes back to whether current managers have the way and the will to engage in this process which itself is innovative.

\section{Future research}

Future research must focus on innovation learning with an eye of understanding how marketing practices and market orientation develop in transforming firms. Mandatory restructuring to date has not brought about the expected results. What will? An important area for research is to understand how the market behavior of competitors, especially foreign firms affects the adoption of marketing practices by these firms. Clearly as the current managers retire understanding the role of younger managers will be an important area to consider. It may well be that in 10 or 15 years when the top management is composed primarily of people who are not attached to the past and who have worked through the market economy that these enterprises may have become market oriented. Regardless of what research is undertaken, it is clear that it 
must be cast within the historical context and the transformation programs. It is all too easy to apply western concepts and models when they are not warranted.

\section{Table 1: Evaluation of Market Orientation Components}

\begin{tabular}{|l|c|c|c|c|}
\hline Company: & JORAN & HP & KAUCUK & SPOLCHEMIE \\
\hline $\begin{array}{l}\text { Component: } \\
\text { Oustomer } \\
\text { Orientation }\end{array}$ & $\mathrm{I}$ & $\mathrm{I}$ & $\mathrm{N}$ & $\mathrm{N}$ \\
\hline $\begin{array}{l}\text { Competitor } \\
\text { Orientation }\end{array}$ & $\mathrm{P}$ & $\mathrm{P}$ & $\mathrm{A}$ & $\mathrm{P}$ \\
\hline $\begin{array}{l}\text { Inter-functional } \\
\text { Coordination }\end{array}$ & $\mathrm{I}$ & $\mathrm{I}$ & $\mathrm{N}$ & $\mathrm{N}$ \\
\hline \begin{tabular}{l} 
Implementation: \\
\hline $\begin{array}{l}\text { Customer } \\
\text { Information }\end{array}$
\end{tabular}$\quad \mathrm{I}$ & $\mathrm{I}$ & $\mathrm{N}$ & $\mathrm{N}$ \\
\hline $\begin{array}{l}\text { Develop } \\
\text { Strategy }\end{array}$ & $\mathrm{I}$ & $\mathrm{I}$ & $\mathrm{P}$ & $\mathrm{P}$ \\
\hline $\begin{array}{l}\text { Implement } \\
\text { Strategy }\end{array}$ & $\mathrm{I}$ & $\mathrm{I}$ & $\mathrm{A}$ & $\mathrm{A}$ \\
\hline
\end{tabular}

Where:

A is absent from market planning activities.

$\mathrm{P}$ is present but not implemented.

I indicates component is at least partially implemented.

$\mathrm{N}$ indicates that the component is not clearly understood.

\section{References}

Akimova, I. (1997): Marketing Approaches and Organization for Marketing in Ukraine, in: Journal for East European Management Studies, No. 2, pp. 237-258.

Brown, L. A. (1981): Innovation Diffusion: A New Perspective. Methuen.

Clark, E. and A. Soulsby (1996): The Re-formation of the Managerial Elite in the Czech Republic, in Europe-Asia Studies, No. 48, pp. 285-303.

Fredrick, R. (1994): Enterprise Restructuring in the Context of Privatization, in Centre for Co-Operation with Economies in Transformation, Trends and Policies in Privatization, Vol. LI, No. 1., pp. 63-73. 
Estrin, S., Gelb, A., and Singh, I. (1995): Shocks and Adjustments by Firms in Transition: A Comparative Study, Journal of Comparative Economics,

No. 21, pp. 131-155.

Edwards, V., and Lawrence, P. (1994): Management Change in East Germany, Routledge.

Hitchens, K.H., Birne, J. E., Hamar, J., Wagner, K., and Zeinplinerova, A. (1995):

Competitiveness of Industry in the Czech Republic and Hungary. Aldershot.

Hooley, G. J., Beracs, J. and Kolos, K. (1993), Marketing Strategy Typologies in

Hungary, in European Journal of Marketing, No. 27, pp. 80-101.

Matesova, J. (1994). Will the Manufacturing Heart Beat Again? East European

Economics, No. 31, pp. 3-35.

Narver, J. C., and Slater, S. F. (1990): The Effect of Market Orientation on

Business Profitability, Journal of Marketing, No. 54., pp. 20-35.

Newman, K. L. and Nollen, S. D. (1996): Managerial Challenges During Organizational

Re-Creation: Industrial Companies in the Czech Republic in Ullman, A. and Lewis, A. eds.: Privatization and Entreprenuership: The Managerial Challenges

In Central and Eastern Europe. International Business Press.

Pohl, G., Djankov, S., and Anderson, R. E. (1996). Restructuring Large Industrial Firms In Central and Eastern Europe, An Empirical Analysis. The World Bank.

Pohl, G., Anderson, R. E., Claessens, S., and Djankov, S. (1997). Privatization and Restructuring in Central and Eastern Europe. The World Bank.

Romanelli, E. and M. L. Tushman (1994): Organizational Transformation as Punctuated Equilibrium, Academy of Management Journal No. 37, pp. 1141-1166.

Ruekert, R. W., (1992): Developing a Market Orientation: An Organizational Strategy Perspective, International Journal of Research in Marketing, No. 9, pp. 225-245.

Savitt, R. (1998): The Prospects of Becoming Market Oriented: Evidence from the

Czech Republic, William Davidson Institute at the University of Michigan Business School Seminar, Marketing Issues in Transitional Economies. (1996): Bonding Well, Central European, September, pp. 20-21. (1997): Private Parts, Business Central Europe, December/January, p. 68. 